\title{
Length Effect on Load Bearing Capacities of Friction Rock Bolts
}

\author{
Eren Komurlu*, Serhat Demir² \\ ${ }^{1}$ Department of Civil Engineering, \\ Giresun University, 28100, Giresun, Turkey \\ 2 Department of Civil Engineering, \\ Karadeniz Technical University, 61080, Trabzon, Turkey \\ * Corresponding author, e-mail: ekomurlu@giresun.edu.tr
}

Received: 26 March 2019, Accepted: 18 May 2019, Published online: 05 June 2019

\begin{abstract}
Change in the load bearing capacity of the split set type friction rock bolts with variations of bolt lengths was investigated within this study. To determine a relation between the load bearing capacity and bolt length parameters, different friction bolt models with various lengths were analyzed with a numerical modelling study. In addition, a series of pull-out tests was carried out to evaluate the load bearing capacities of the split set type friction rock bolts with different lengths. The load bearing capacity of the bolts was found to decreasingly increase with the increase in the bolt length. As an outcome of this study, a relation between the load bearing capacity and rock bolt length parameters is suggested in accordance with the results obtained from both numerical and experimental studies.
\end{abstract}

Keywords

friction rock bolts, split sets, pull-out test, load bearing capacity

\section{Introduction}

For a long time, rock bolts have been used for the purpose of reinforcing and supporting underground excavations in civil and mining engineering. According to their anchoring mechanism, rock bolts can be classified into various groups. The friction bolts are a type with the ability to supply support pressure due to the friction between the bolt shanks and the rock surfaces of drill holes. The split sets consisting of the tube and plate parts are the first and most widely used type of friction rock bolts. As split sets are inserted into drill holes with slightly lower diameter than that of the rock bolts, the radial spring force is generated by the compression of the tube with a slit in the cross-section of $C$ shape. The compression of the tube provides the frictional anchorage in drill holes.

The split sets are popular in rock engineering because of their advantages such as practical application, being able to directly start bearing load as being inserted, retaining a close load bearing capacity to its peak despite the high deformations in tunnels. Even though the sliding at the friction interface starts, spit sets can supply a good support pressure depending on various parameters such as the normal stress at the friction interface, the friction coefficient and friction bond length [1-3].

The split sets used in rock engineering generally have lengths from 2 meters to 3 meters. Depending on the site, split sets can also be applied with different lengths varying from one meter to four meters [4-7]. For supplying a sufficient support pressure, the friction bond length should be enough long. It is well-known that length is an important parameter for load bearing capacities of rock bolts. The load bearing capacity increases with an increase in rock bolt lengths. On the other hand, variations in the load bearing capacity per unit length is another topic to investigate whether the length effect on the load bearing capacity is diminished in case of using high bolt lengths. The relation between changes in the friction bolt length and the load bearing capacity was aimed to be investigated in detail by this numerical and experimental study.

A popular test to determine load bearing capacities of rock bolts, the pull-out test was performed in the experimental part of this study. The purpose of the pull out test is to evaluate the bearing capacities of rock bolts under axial loading condition. The pull-out test helps to verify the effectiveness of rock bolts. In the test, split sets inserted into drill holes were held from the collars at the back ends of the tubes and pulled out by the hydraulic jack of the 
equipment. The axial load is applied on the rock bolts. In the pull-out tests of the friction rock bolts, the load capacity is the maximum load borne by the friction bond between rock and bolt surfaces, which is generally reached just before the start of sliding of the steel tube of split sets. The steel split sets can be moved sliding in drill holes under a slightly lower load than the peak values. As the split set tubes need nearly constant and a close load level to the peak load to keep their sliding in the drill holes, ideal support reactions are obtained from them [8-10]. That kind of load and displacement behavior makes the split set bolts to have good amount of energy absorption capacity [11-15].

The stress distribution in the bolt steel and maximum stresses induced in the bolt body vary with the change in the bolt length. In case of longer friction bond lengths than a critical length, bolt steel fails instead of the sliding at the friction surface. Therefore, the friction load bearing capacity also depends on the bolt material strength as well as the friction coefficient, stresses on the friction surface and the bolt length [16-18]. Even if the friction load capacity can be bettered by modifications in various parameters for increasing the friction performance, the bolt bearing capacity maximizes at a load causing the yield of the bolt shank.

\section{Numerical study}

\subsection{Methodology}

To investigate their frictional load bearing capacities, rock bolts with different lengths ( $1 \mathrm{~m}, 2 \mathrm{~m}, 3 \mathrm{~m}, 4 \mathrm{~m}, 5 \mathrm{~m})$ were modelled. The split set tubes with the outside diameter of $30 \mathrm{~mm}$ were fully contacted into the drills in rock blocks with $350 \mathrm{~mm} \times 350 \mathrm{~mm}$ width and height sizes and a meter higher length than those of the bolts. As shown in Fig. 1, the pull-out test was modelled by axial loading in the direction of the bolt shanks. Load was applied from the bolt end being outside of the drill hole. The mesh size in the rock models was chosen to be $2 \mathrm{~mm}$ around drill holes where is the most critical part for the start of failure and increase from $2 \mathrm{~mm}$ by depending on the distance from the drill hole wall (Fig. 1). Various finite element models with different meshes were analyzed in an effort to ensure that the selected meshes are dense enough to provide sufficient solution convergence. In the steel rock bolt models, the mesh size was selected to be vary about $2 \mathrm{~mm}$, which slightly increased from the inner to outer side of the $C$ shape tube cross-section. On the other hand, the mesh size along the bolt length was constant and $2.5 \mathrm{~mm}$. Some figures of bolt-inserted rock block models with different lengths are given in Fig. 2.

Eight-node solid brick elements (Solid65) were used for the three-dimensional modelling, which have the capability of cracking in tension, crushing in compression, plastic deformation, and three degrees of freedom at each node, including transition in the nodal $x, y$ and $z$ directions. Rock and steel materials were modelled by considering the linear and non-linear properties defining the behaviors of the elements. The rock models were defined as linear elastic until the crack initiation occurs. After the crack initiation, change of the normal and shear stresses has been re-calculated by the program. The re-calculated shear stresses were transferred by the plasticity due to the generated open and closed cracks. The bolt steel material models were defined as linear elastic until the yielding stress is reached. The steel material was modelled to plastically deform under constant load level. However, quite high bolt lengths to reach the yield strength values of the steel material were not analyzed in this study due to the aim of investigating a

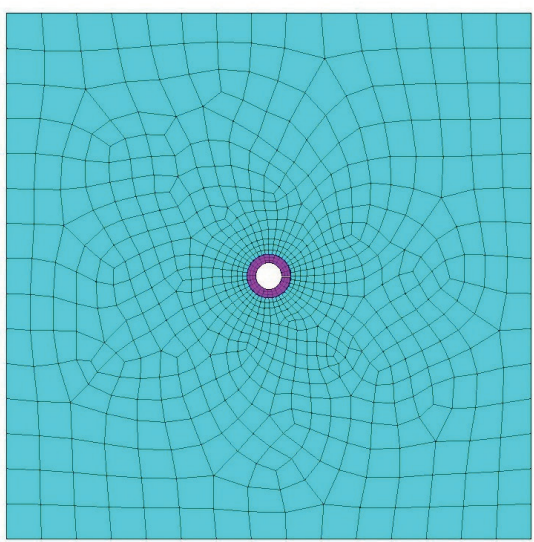

b

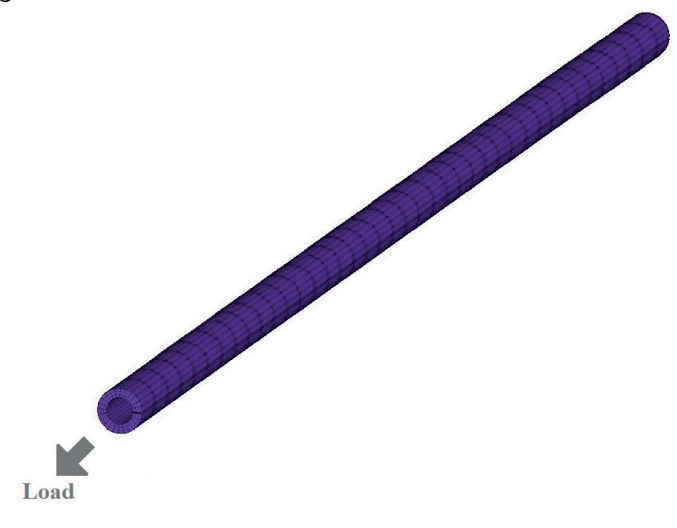

Fig. 1 Numerical models and meshing: a) cross-section of a tube inserted rock block, b) a bolt model 

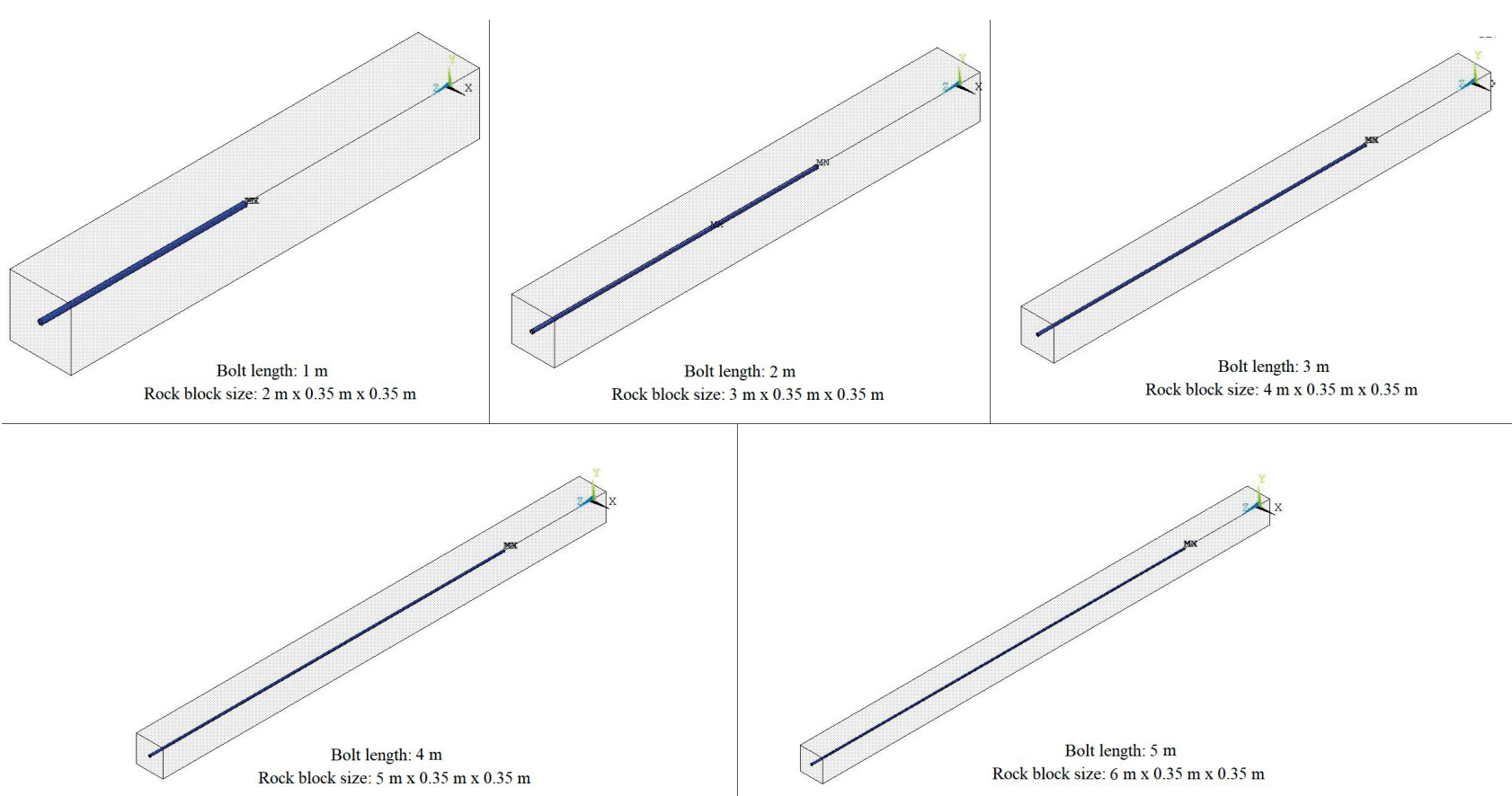

Fig. 2 Rock bolt inserted rock blocks with different lengths from $2 \mathrm{~m}$ to $6 \mathrm{~m}$ (Rock bolt lengths from $1 \mathrm{~m}$ to $5 \mathrm{~m}$ )

the friction capacity change. In the numerical models, the sliding started as the adhesion between bolt steel and rock surfaces is achieved and continued under a constant load level. The normal stress applied to the contact between rock and bolt steel was $0.5 \mathrm{MPa}$ in the numerical analyses. For applying the normal stresses at the contact, hydrostatic pressure was applied from inside of the steel tube.

For the displacement-controlled loading, loads were divided into multiple sub-steps until the total load was achieved. Stress distributions and failure mechanisms were plotted for all the models. A static analysis was performed for each of the models, and the full Newton-Raphson method was used for non-linear analysis. The material properties for rock, bolt steel and friction interface of rock and bolt contact are given in Table 1. To neglect the failure of steel and failure in rock material, relatively high strength values were selected for rock and steel materials. The steel and rock failures were theoretically eliminated in this study to investigate the load bearing capacity of the friction surfaces for a wide change in the bolt length.

Table 1 Material properties in the numerical study

\begin{tabular}{lccc}
\hline Property & Rock & Bolt & Friction interface \\
\hline UTS $(\mathrm{MPa})$ & 20 & 330 & 0 \\
UCS $(\mathrm{MPa})$ & 200 & 350 & 200 \\
E $(\mathrm{GPa})$ & 100 & 250 & - \\
$v$ & 0.27 & 0.25 & - \\
Adhesion $(\mathrm{MPa})$ & - & - & 5 \\
\hline
\end{tabular}

To investigate whether friction forces at the bolt and rock contact have an effect on relation between length and the load bearing capacity parameters, different friction coefficient values $(\mu)$ of 0.2 and 0.5 were used in numerical analyses.

\subsection{Results}

According to the results of the numerical analyses, the tensile strain values increase from front end to the back end which is the load applying side of the bolts. As seen in Fig. 3, the maximum stress in the bolt shank is induced at the back end part. Because of the increase in strain of the steel, the friction forces at the contact of the rock and bolt steel surfaces also maximize at the back end part. Therefore, the critical location for the start of the adhesive failure was found to be the entrance part of drill holes where is near-by the load applied. As the stresses at the friction interface reached its maximum value, the bolt shank started to slide in the hole. The pull-out test loads and maximum stresses induced in the bolt shanks at the start of the sliding in the hole are given in Tables 2-4, respectively. Additionally, changes in the pull-out test loads per bolt length parameter are shown in Fig. 4 and Fig. 5. According to the results obtained from the numerical analyses, load bearing capacity and the bolt length parameters were related as seen in Eqs. (1) and (2), which respectively give the change in load bearing capacity per a unit bolt length and load bearing capacity of the total bolt 
length. It should be noted herein that the suggestions given in the following equations are exclusively for split set type rock bolts with different lengths from $1 \mathrm{~m}$ to $5 \mathrm{~m}$.

$F_{p}=F_{1}(1-0.12(n-1))$,

$F_{t}=F_{1}(1-0.12(n-1)) n=F_{1}\left(n-0.12 n^{2}+0.12 n\right)$,

where, $n$ is the bolt length (m), $F_{1}$ is load bearing capacity of bolts with $1 \mathrm{~m}$ length $(\mathrm{kN}), F_{p}$ is load bearing capacity of bolts per $1 \mathrm{~m}$ length $(\mathrm{kN} / \mathrm{m})$ and $F_{t}$ is the maximum pull-out test load of a bolt with $n$ meters length $(\mathrm{kN})$.

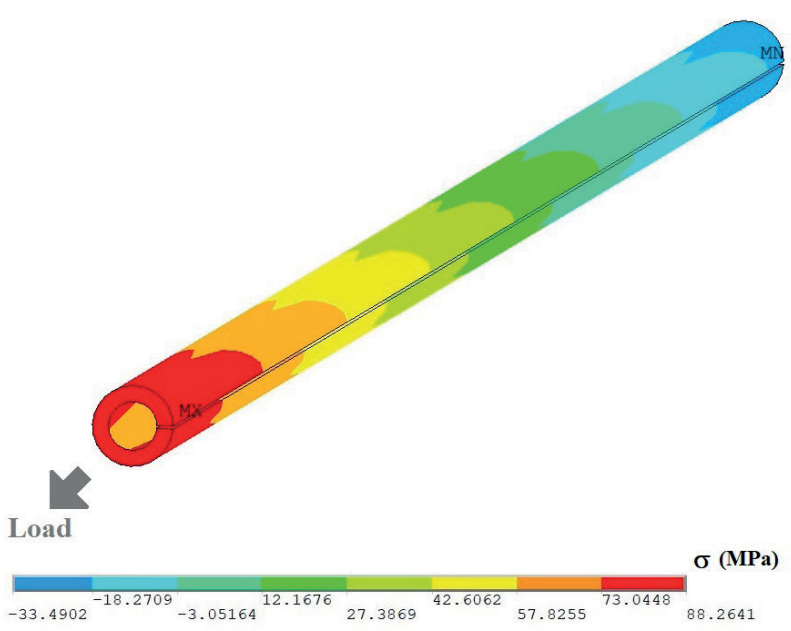

Fig. 3 Stress distribution through the bolt body with $1 \mathrm{~m}$ length

$$
\text { (not to scale, } \mu: 0.5 \text { ) }
$$

Table 2 Load bearing capacities of rock bolts with different lengths $(\mu: 0.5)$

\begin{tabular}{lcc}
\hline Bolt length $(\mathrm{m})$ & $\begin{array}{c}\text { Load bearing Capacity } \\
(\mathrm{kN})\end{array}$ & $\begin{array}{c}\text { Load capacity per } \\
\text { meter }(\mathrm{kN} / \mathrm{m})\end{array}$ \\
\hline 1 & 19.5 & 19.5 \\
2 & 34.3 & 17.2 \\
3 & 41.0 & 13.7 \\
4 & 47.7 & 11.9 \\
5 & 50.8 & 10.2 \\
\hline
\end{tabular}

Table 3 Load bearing capacities of rock bolts with different lengths

\begin{tabular}{lcc}
\multicolumn{3}{c}{$(\mu: 0.2)$} \\
\hline Bolt length $(\mathrm{m})$ & $\begin{array}{c}\text { Load bearing Capacity } \\
(\mathrm{kN})\end{array}$ & $\begin{array}{c}\text { Load capacity per } \\
\text { meter }(\mathrm{kN} / \mathrm{m})\end{array}$ \\
\hline 1 & 13.4 & 13.4 \\
2 & 23.8 & 11.9 \\
3 & 29.1 & 9.7 \\
4 & 33.5 & 8.4 \\
5 & 35.4 & 7.1 \\
\hline
\end{tabular}

Table 4 Maximum stresses in the bolt shank when the load bearing capacity is reached

\begin{tabular}{lcc}
\hline Bolt length (m) & Maximum tensile stress in the bolt shank (MPa) \\
\hline 1 & $\mu: 0.5$ & $\mu: 0.2$ \\
2 & 88 & 60 \\
3 & 150 & 101 \\
4 & 213 & 142 \\
5 & 271 & 184 \\
\hline
\end{tabular}

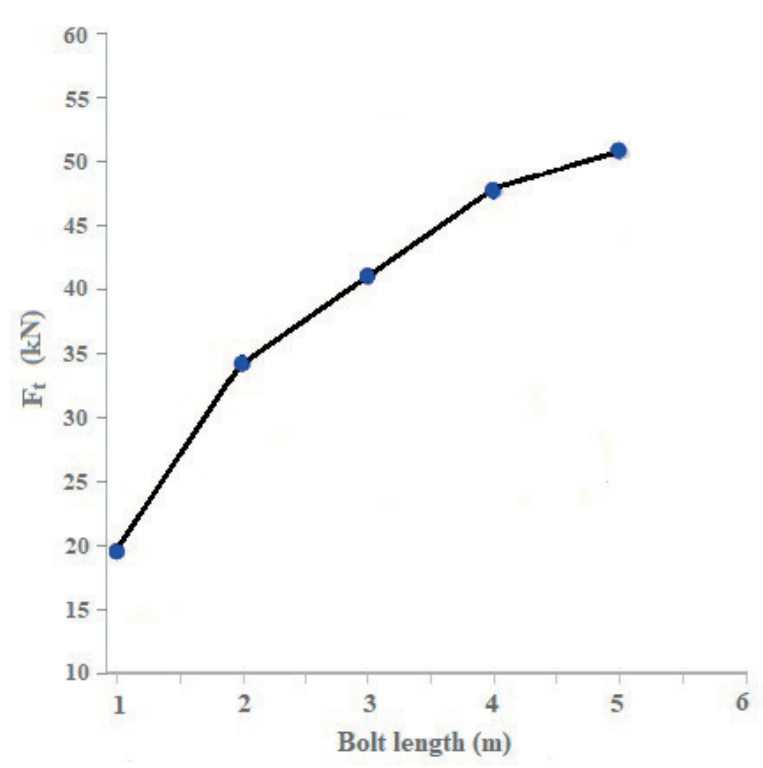

a)

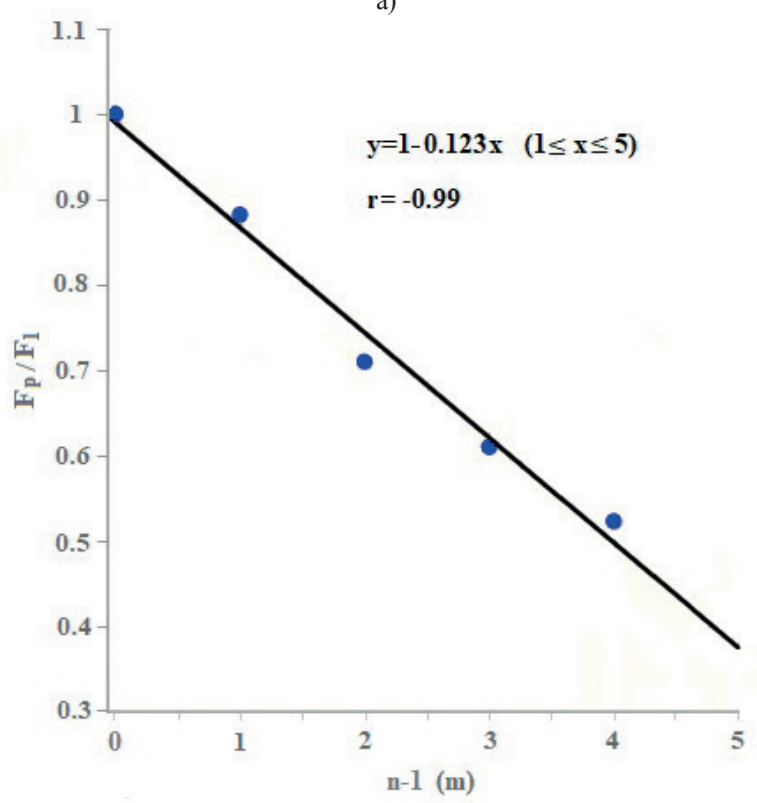

b)

Fig. 4 Load bearing capacities for different bolt lengths $\left(F_{t}\right.$ : load bearing capacity of a bolt, a) $F_{1}$ : load bearing capacity of bolts with $1 \mathrm{~m}$ length, b) $F_{p}$ : load bearing capacity per 1 meter length $\left(F_{p}=F_{t} / n\right), n$ is the bolt length, $\left.\mu: 0.5\right)$ 

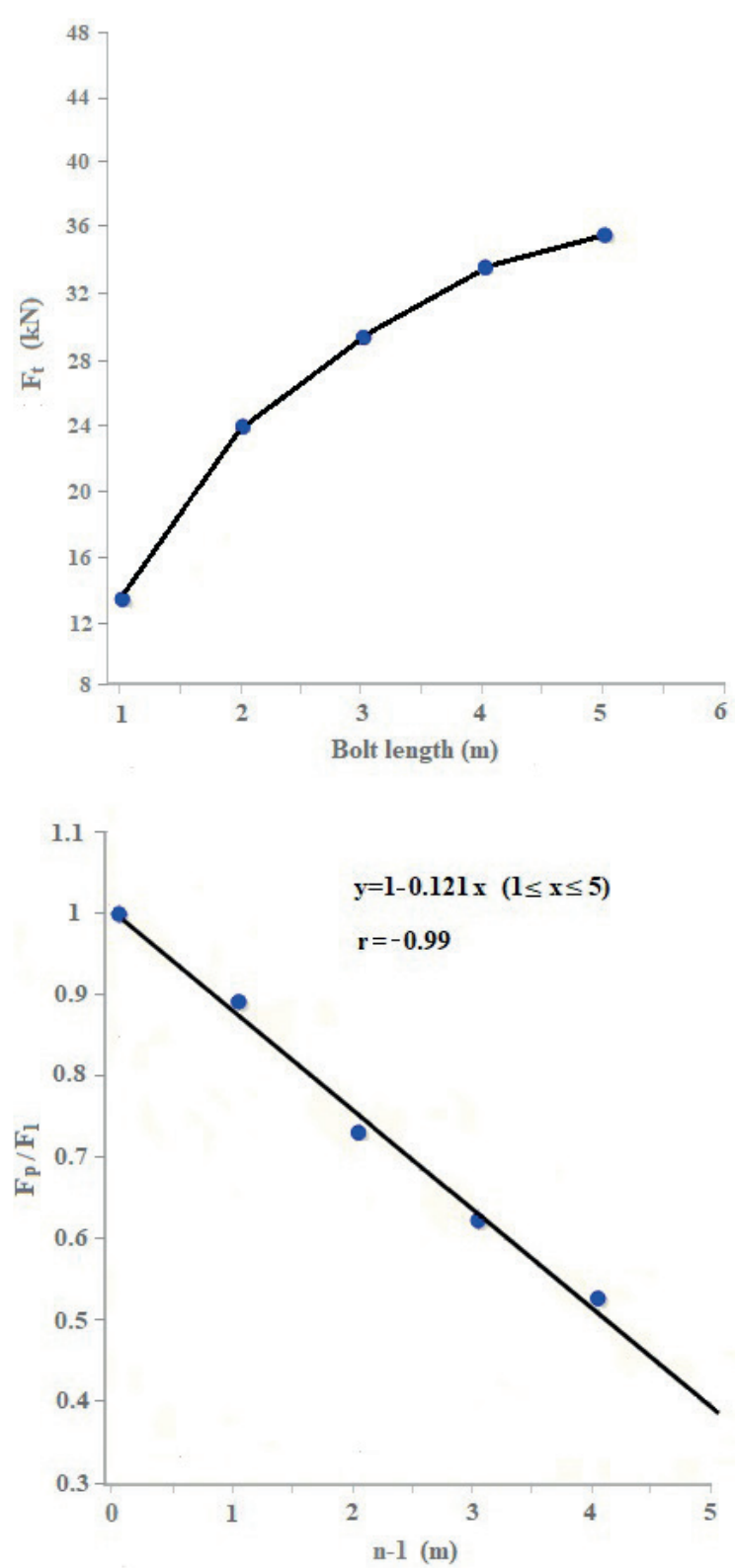

Fig. 5 Friction load capacities for different bolt lengths $(\mu: 0.2)$

\section{Experimental study}

\subsection{Materials and methods}

A field study was performed at the Akarsen copper mine, which is an underground rock engineering site in Artvin, a city in the Black Sea region of Turkey. The split set tubes with different lengths of $1.0 \mathrm{~m}$ and $2.5 \mathrm{~m}$ were purchased from the same manufacturer and used in the field study (Fig. 6). Both of the split sets are made of same steel material and have same nominal diameter of $39 \mathrm{~mm}$. The steel split sets with the nominal diameter of $39 \mathrm{~mm}$ were installed in drill holes of $36 \mathrm{~mm}$ diameter, using a rock bolter machine which is able to first drill holes into the rock mass and insert bolts later on. In total, 18 rock bolts were inserted into the holes drilled in three different rock formations of the mine. Within this field study, a chalcopyrite ore, limestone and dacite formations were chosen for investigation of the length effect on the load bearing capacities of the bolts inserted in various rock contact conditions. A day after the installation of the rock bolts, load bearing capacities were evaluated carrying out the pullout test in the mine (Fig. 7).
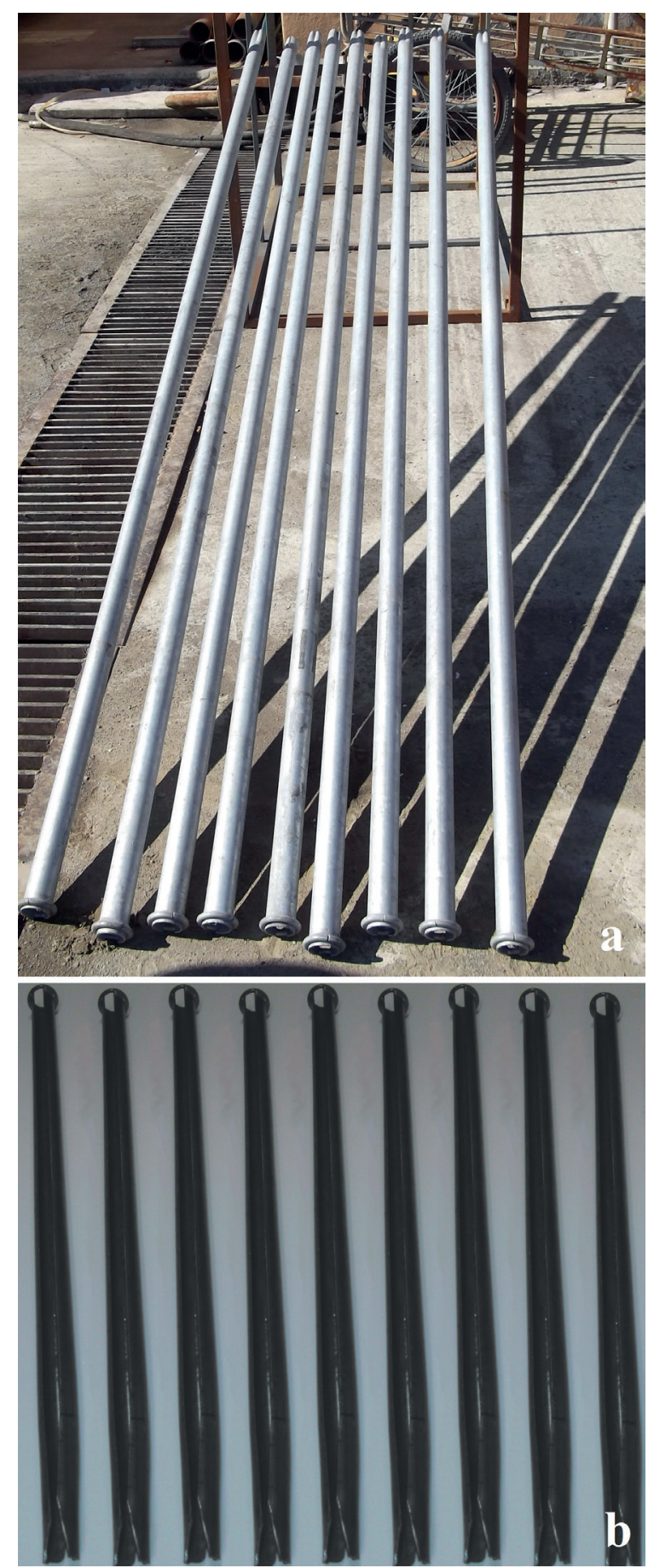

Fig. 6 Rock bolts used in the field tests:

a) split sets with the length of $2.5 \mathrm{~m}, \mathrm{~b}$ ) split sets with the length of $1 \mathrm{~m}$ 
Table 5 Loads measured from the Pull-out test

( $F_{1}$ : load bearing capacity of bolts with $1 \mathrm{~m}$ length, $F_{25}$ : load bearing capacity of bolts with $2.5 \mathrm{~m}$ length)

\begin{tabular}{|c|c|c|c|c|c|c|}
\hline & \multicolumn{2}{|c|}{ Chalcopyrite Ore 1} & \multicolumn{2}{|c|}{ Limestone } & \multicolumn{2}{|c|}{ Dacite } \\
\hline & $F_{1}(\mathrm{kN})$ & $F_{2.5}(\mathrm{kN})$ & $F_{1}(\mathrm{kN})$ & $F_{2.5}(\mathrm{kN})$ & $F_{1}(\mathrm{kN})$ & $F_{2.5}(\mathrm{kN})$ \\
\hline Replicate 1 & 29 & 52 & 25 & 49 & 27 & 61 \\
\hline Replicate 2 & 25 & 56 & 22 & 45 & 30 & 58 \\
\hline Replicate 3 & 26 & 50 & 22 & 46 & 31 & 54 \\
\hline Mean & 27 & 53 & 23 & 47 & 29 & 58 \\
\hline
\end{tabular}

Table 6 Ratio between load bearing capacities of bolts with different

\begin{tabular}{lc}
\multicolumn{2}{c}{ lengths of $2.5 \mathrm{~m}$ and $1.0 \mathrm{~m}\left(F_{2.5} / F_{1}\right)$} \\
\hline Rock Formation & $F_{2.5} / F_{1}$ \\
\hline Chalcopyritic Ore & 1.96 \\
Limestone & 2.04 \\
Dacite & 2.00 \\
Numeric Model (Eq. (2)) & 2.05 \\
\hline
\end{tabular}

Table 7 A comparison between experimental results and Eq. (1) for bolts with the length of $2.5 \mathrm{~m}\left(F_{p}=\right.$ load bearing capacity per one meter length of bolts, $F_{2.5}=$ load bearing capacity of bolts with the length of $2.5 \mathrm{~m}$ )

\begin{tabular}{lcc}
\hline Rock Formation & $F_{p}($ Eq. $(1))$ & $F_{p}\left(F_{2.5} / 2.5 \mathrm{~m}\right)$ \\
\hline Chalcopyritic Ore & $22.1 \mathrm{kN}$ & $21.2 \mathrm{kN}$ \\
Limestone & $18.9 \mathrm{kN}$ & $18.8 \mathrm{kN}$ \\
Dacite & $23.8 \mathrm{kN}$ & $23.2 \mathrm{kN}$ \\
\hline
\end{tabular}

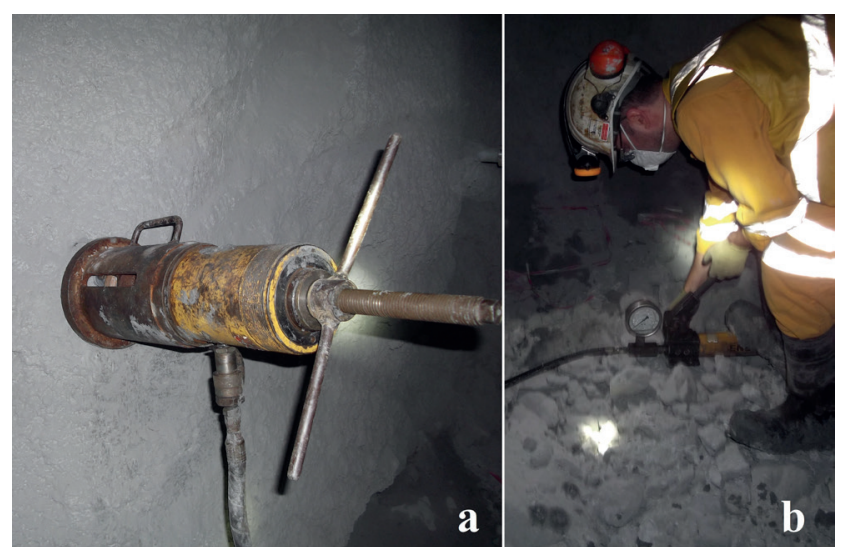

Fig. 7 Pull out test: a) bolt pulling, b) loading by using the jack handle

\subsection{Results}

The pull-out test results are given in Tables 5 and 6 . According to the pull-out test results, load capacity increased by 2 times when the length increases by 2.5 (2.5/1.0) times. That finding verifies Eqs. (1) and (2) which were derived in accordance with the results of the numerical analyses. Tables 6 and 7 show the similarity between results obtained from experimental and numerical studies.

\section{Discussions}

The numerical part of this study was carried out with the aim of modelling the Pull-out test for determination of the load bearing capacities of friction bolts with different lengths. The frictional load bearing capacity of the bolts was found to increase with an increase in the bolt length. Rate of the increase in the bearing capacity of the friction bolts was investigated within this study. The load bearing capacity of friction bolts was found to be not directly proportional to the lengths of the bolts. It was determined to decreasingly increase with the increase of the bolt length. The stresses at the friction surface was determined to maximize near the tunnel wall side of the drill hole end which was also designated as the critical location for the failure initiation by previous researches [19-22].

Because of the decrease in load bearing values per a friction length, the effect of increase in the bolt length on the frictional load bearing capacity of the split sets was found to be diminished in case of using high bolt lengths. The findings of this study should not be considered to infer that rock bolt length is not needed to be lengthened. For instance, rock bolts should have enough length to support the plastic zone around tunnels by being inserted in the elastic zone. Besides, the length of the bolt in the elastic zone should be high enough for being able to bear the plastic zone load [23-28]. The needed bolt length depends on various parameters like tunnel cross-section shape and size, in situ stress distribution and rock mass quality. The aim of this study was only to investigate frictional load bearing capacity variations of the split sets with the change in its length parameter.

Since the increase in bolt length causes also increases in the stresses induced in the bolt steel material, the steel failure becomes possible instead of the sliding at the friction surface. The increase in the bolt length sometimes has not a positive effect on the load capacity, because the strength of the bolt steel material can make limitations in case of using high bolt lengths [29-32]. 
The maximum bolt length was $5 \mathrm{~m}$ in this study. For the split set type friction bolts, $5 \mathrm{~m}$ is significantly over the widely used lengths. The maximum load capacity of the steel tube is typically about $75 \mathrm{kN}$. Generally, 3 meters length is enough for steel material failure in pull-out tests of the split sets. In addition to the possible steel failure, high bolt lengths are not used in the split set applications due to the buckling during the insertion. To eliminate this problem, bolt lengths are generally smaller than $3 \mathrm{~m}$ in applications [33-35]. Therefore, the bolt length variations interval analyzed within this study can be assessed to be enough wide in terms of investigating differences in the frictional load capacity of the split sets.

The friction coefficient changes the stress distribution in the steel material and critical bolt length for the steel failure [36-38]. The relation between the frictional load bearing capacity and bolt length variations was determined to be same for different friction coefficient values for the rock and

\section{References}

[1] Komurlu, E., Kesimal, A. "Improved Performance of Rock Bolts using Sprayed Polyurea Coating", Rock Mechanics and Rock Engineering, 48(5), pp. 2179-2182, 2015.

https://doi.org/10.1007/s00603-014-0696-4

[2] Komurlu, E., Kesimal, A. "Experimental Study on Usability of Friction Rockbolts with Plastic Bodies", International Journal of Geomechanics, 17(9), 2017.

https://doi.org/10.1061/(ASCE)GM.1943-5622.0000960

[3] Hassell, R., Villaescusa, E. "Overcoring techniques to assess in situ corrosion of galvanised friction bolts", In: Proceeding of the 24th International Conference on Ground Control in Mining, Morgantown, WV, USA, 2005, pp. 349-356.

[4] Jennmar "Selected Ground Control Products Catalogue", [online] Available at: www.jennmar.com [Accessed: 3 May 2015]

[5] Split Set ${ }^{\circledR}$ "Split Set Stabilizers SS-39 Product Brochure", [pdf] International Rollforms, Inc., Deptford, New Jersey, USA, Available at: http://www.splitset.com/pdf/Form_16516_ASS_39. pdf [Accessed: 17 September 2014]

[6] Hemphill, G. B. "Practical Tunnel Construction", 1st ed., John Wiley and Sons Inc., Hoboken, NJ, USA, 2013.

https://oi.org/10.1002/9781118350270

[7] Komurlu, E., Kesimal, A., Colak, U. "Polyurea type thin spray-on liner coating to prevent rock bolt corrosion", In: Proceedings of the 8th Asian Rock Mechanics Symposium, Saporro, Japan, 2014, pp. 1389-1397.

[8] Williams, T., Denton, D., Johnson, J., Maciosek, F., Maslowski, M. "The use of instrumented split-set rock bolts to monitor strain in the walls of a deep underground mine stope", Transactions of the Society for Mining, Metallurgy, and Exploration, 316, pp. 207-214, 2004.

[9] Thompson, A. G., Villaescusa, E. "Case Studies of Rock Reinforcement Components and Systems Testing", Rock Mechanics and Rock Engineering, 47(5), pp. 1589-1602, 2014.

https://doi.org/10.1007/s00603-014-0583-z bolt contact. Therefore, it was assessed that there is no need to use the friction coefficient parameter in Eqs. (1) and (2). The equations suggested in this study are valid for different friction conditions. The results obtained from experimental and numerical studies were quite similar as seen from the ratio of $F_{2.5} / F_{1}$ which was nearly same in both analyses.

\section{Conclusions}

The frictional load bearing capacity variations of the split sets with the change in the bolt length parameter were investigated within this study. The load bearing capacity per a friction length was found to decrease with an increase in the length of the bolt shank. Therefore, the load bearing capacity was found to be not directly proportional to the length. According to the results of both experimental and numerical analyses, Eqs. (1) and (2) can be used to calculate the change of the load bearing capacity of the friction bolts.

[10] Akkiris, D. "Advantages of the frictional rock bolt swellex", In: Proceedings of 11th Regional Rock Mechanics Symposium of Turkey, Turkish National Society for Rock Mechanics, Afyonkarahisar, Turkey, 2014, pp. 247-252.

[11] Li, C. C. "Field Observations of Rock Bolts in High Stress Rock Masses", Rock Mechanics and Rock Engineering, 43(4), pp. 491496, 2010.

https://doi.org/10.1007/s00603-009-0067-8

[12] Li, C. C., Stjern, G., Myrvang, A. "A review on the performance of conventional and energy-absorbing rockbolts", Journal of Rock Mechanics and Geotechnical Engineering, 6(4), pp. 315-327, 2014. https://doi.org/10.1016/j.jrmge.2013.12.008

[13] Li, C. C. "Principles of rockbolting design", Journal of Rock Mechanics and Geotechnical Engineering, 9(3), 396-414, 2017. https://doi.org/10.1016/j.jrmge.2017.04.002

[14] Stacey, T. R. "Addressing the Consequences of Dynamic Rock Failure in Underground Excavations", Rock Mechanics and Rock Engineering, 49(10), pp. 4091-4101, 2016. https://doi.org/10.1007/s00603-016-0922-3

[15] He, M., Gong, W., Wang, J., Qi, P., Tao, Z., Du, S., Peng, Y. "Development of a novel energy-absorbing bolt with extraordinarily large elongation and constant resistance", International Journal of Rock Mechanics and Mining Sciences, 67, pp. 29-42, 2014. https://doi.org/10.1016/j.ijrmms.2014.01.007

[16] Li. C. C. "A Practical Problem with Threaded Rebar Bolts in Reinforcing Largely Deformed Rock Masses", Rock Mechanics and Rock Engineering, 40(5), pp. 519-524, 2007. https://doi.org/10.1007/s00603-006-0094-7

[17] Qingliang, C., Huaqiang, Z., Zhihong, X., Shiping, S. "Anchoring mechanism and application of hydraulic expansion bolts used in soft rock roadway floor heave control", International Journal of Mining Science and Technology, 23(3), pp. 323-328, 2013. https://doi.org/10.1016/j.ijmst.2013.05.017 
[18] Komurlu, E. "Usability of Various Engineering Polymers as Rock Bolt Materials", PhD Thesis, Karadeniz Technical University, 2016.

[19] Nicholson, L., Hadjigeorgiou, J. "Interpreting the results of in situ pull tests on Friction Rock Stabilizers (FRS)", Mining Technology, 127(1), pp. 12-25, 2018. https://doi.org/10.1080/14749009.2017.1296669

[20] Li, C. C., Doucet, C. "Performance of D-Bolts Under Dynamic Loading", Rock Mechanics and Rock Engineering, 45(2), pp. 193204, 2012.

https://doi.org/10.1007/s00603-011-0202-1

[21] Cao, C., Nemcik, J., Aziz, N., Ren, T. "Failure modes of rockbolting", In: 12th Coal Operators' Conference, Wollongong, Australia, 2012, pp. 137-153. [online] Available at: https://ro.uow.edu.au/ coal/401/ [Accessed: 12 February 2019]

[22] Thompson, A. G., Villaescusa, E., Windsor, C. R. "Ground Support Terminology and Classification: An Update", Geotechnical and Geological Engineering, 30(3), pp. 553-580, 2012.

https://doi.org/10.1007/s10706-012-9495-4

[23] Yang, S.-Q., Chen, M., Jing, H.-W., Chen, K.-F., Meng, B. "A case study on large deformation failure mechanism of deep soft rock roadway in Xin'An coal mine, China", Engineering Geology, 217, pp. 89-101, 2017.

https://doi.org/10.1016/j.enggeo.2016.12.012

[24] Zhao, H., Ru, Z., Zhu, C. "Reliability-based Support Optimization of Rockbolt Reinforcement around Tunnels in Rock Masses", Periodica Polytechnica Civil Engineering, 62(1), pp. 250-258, 2018. https://doi.org/10.3311/PPci.10420

[25] Komurlu, E., Kesimal, A., Aksoy, C. O. "Use of Polyamide-6 Type Engineering Polymer as Grouted Rock Bolt Material", International Journal of Geosynthetics and Ground Engineering, 3, 2017. https://doi.org/10.1007/s40891-017-0114-6

[26] Kolymbas, D. "Tunnelling and Tunnel Mechanics: A Rational Approach for Tunnelling", 2nd ed., Springer, Berlin, Germany, 2005.

[27] Yang, R., Wang, M., Ma, X., Wang, Y., Rostami J. "Study of rock stability for mine entries in Ganhe coal mine", International Journal of Oil, Gas and Coal Technology, 15(2), pp. 166-189, 2017. https://doi.org/10.1504/ijogct.2017.084313

[28] Meng, Q., Zhao, H., Zhu, C., Ru, Z. "Analytical and Reliability Study of the Tunnel with Rockbolts in Rock Masses", Periodica Polytechnica Civil Engineering, 62(3), pp. 783-791, 2018. https://doi.org/10.3311/PPci.11976

[29] Pan, R., Wang, Q., Jiang, B., Li, S. C., Sun, H. B., Qin, Q., Yu, H. C., Lu, W. "Failure of bolt support and experimental study on the parameters of bolt-grouting for supporting the roadways in deep coal seam", Engineering Failure Analysis, 80, pp. 218-233, 2017. https://doi.org/10.1016/j.engfailanal.2017.06.025
[30] Holy, O. "Results and Use of Non-Linear Behavior between Length and Bond Friction of Fully Grouted Rock Bolts in Selected Jointed Rock Masses", GeoScience Engineering, 64(2), pp. 26-39, 2018. [online] Available at: http://gse.vsb.cz/ojs/index.php/GSE/article/ view/183/159 [Accessed: 13 March 2019]

[31] Jalalifar, H. "An analytical solution to predict axial load along fully grouted bolts in an elasto-plastic rock mass", The Journal of the Southern African Institute of Mining and Metallurgy, 111, pp. 809-814, 2011. [online] Available at: http:/www.scielo.org.za/pdf/ jsaimm/v111n11/v111n11a14.pdf [Accessed: 28 January 2019]

[32] Li, C. C, Kristjansson, G., Høien, A. H. "Critical embedment length and bond strength of fully encapsulated rebar rockbolts", Tunnelling and Underground Space Technology, 59, pp. 16-23, 2016. https://doi.org/10.1016/j.tust.2016.06.007

[33] Stimpson, B. "Split Set friction stabilizers: an experimental study of strength distribution and the effect of corrosion", Canadian Geotechnical Journal, 35(4), pp. 678-683, 1998. https://doi.org/10.1139/t98-025

[34] Davison, G. R., Fuller, P. G. "Investigation of expanding Split Sets", In: Proceedings of the Seventh International Symposium on Ground Support in Mining and Underground Construction (Ground Support 2013), Perth, Australia, 2013, pp. 163-170.

[35] Komurlu, E., Kesimal, A. "The Usability of Frictional Rock bolts Bolts with Plastic Body", Scientific Mining Journal, 54(3-4), pp. 41-59, 2015. [online] Available at: http://www.mining.org.tr/article/11dc0b1018c7bcd_ek.pdf [Accessed: 2 October 20159]

[36] Davis, R. L. "Split-set rock bolt analysis", International Journal of Rock Mechanics and Mining Sciences \& Geomechanics Abstracts, 16(1), pp. 1-10, 1979. https://doi.org/10.1016/0148-9062(79)90770-8

[37] Tomory, P. B., Grabinsky, M. W., Curran, J. H., Carvalho, J. "Factors influencing the effectiveness of split set friction stabilizer bolts", CIM Bulletin, 91(1018), pp. 205-214, 1998. [online] Available at: https://www.researchgate.net/publication/292824576_ Factors_influencing_the_effectiveness_of_split_set_friction_stabilizer_bolts [Accessed: 12 February 2019]

[38] Colak, O., Yilmaz, M. "Strength differences of Hole Diameter and Formation on Rock Bolt Applications in Eti Bakir Kure Underground Mine", In: 3rd International Symposium on Underground Excavations for Transportation, Istanbul, Turkey, 2013, pp. 645-648. 